\title{
Evidences of early to late fluid migration from an upper Miocene turbiditic channel revealed by 3D seismic coupled to geochemical sampling within seafloor pockmarks, Lower Congo Basin
}

\author{
A. Gay ${ }^{a^{*}}$, M. Lopez ${ }^{b}$, P. Cochonat ${ }^{c}$, D. Levachéd ${ }^{d}, G$. Sermondadaz ${ }^{d}$ and M. Seranne ${ }^{b}$ \\ ${ }^{a}$ Challenger Division for Seafloor Processes, National Oceanography Centre of Southampton, Southampton, UK \\ ${ }^{b}$ Laboratoire Dynamique de la Lithosphère, Université Montpellier 2, Montpellier, France \\ 'Laboratoire Environnements Sédimentaires, Département Géosciences Marines, IFREMER, Brest, France \\ ${ }^{\mathrm{d}}$ TOTAL, Pau, France \\ *: Corresponding author : Address: National Oceanography Centre of Southampton, Room 786/12, Empress \\ Dock, Southampton SO14 3ZH, UK. Tel.: +44 238059 6614. ayg@noc.soton.ac.uk
}

\begin{abstract}
Using high quality 3D seismic data within the Lower Congo Basin (LCB), we have identified pockmarks that are aligned above the sinuous belt of a buried turbiditic palaeo-channel, $1000 \mathrm{~m}$ beneath the seafloor. Geochemical analyses on cores (GC traces), taken in the centre of four of these pockmarks along this channel, show no clear evidence for migrated oil. But, some features of the GC traces, including elevated baselines $(\mathrm{UCM}>34 \mu \mathrm{g} / \mathrm{g})$ and a broad molecular weight range of $\mathrm{n}$-alkanes with little odd-even preference, may be interpreted as indicating the presence of thermogenic hydrocarbons in the cores.

Seismic profiles show that these pockmarks developed above two main features representative of pore fluid escape during early compaction: (1) closely spaced normal faults affecting the upper 0-800 ms TWT of the sedimentary column. This highly faulted interval (HFI) appears as a hexagonal network in plane view, which is characteristic of a volumetrical contraction of sediments in response to pore fluid escape. (2) Buried palaeo-pockmarks and their underlying chimneys seem to be rooted at the channel-levee interface. The chimneys developed during early stages of burial and are now connected to the HFI.

This study shows that the buried turbiditic channel now concentrates thermogenic fluids that can migrate through early chimneys and polygonal faults to reach the seafloor within some pockmarks. Using a multidisciplinary approach within the Lower Congo Basin, combining 3D seismic data and geochemical analyses on cores, we trace the fluid history from early compaction expelling pore fluids to later migration of thermogenic hydrocarbons.
\end{abstract}

Keywords: Pockmarks; Turbiditic channels; Fluid migration; Polygonal faults; Seismic chimneys; Pipes 


\title{
Evidences of early to late fluid migration from an upper Miocene turbiditic channel revealed by 3D seismic coupled to geochemical sampling within seafloor pockmarks, Lower Congo Basin.
}

\section{A. Gay ${ }^{a *}$, M. Lopez ${ }^{\text {b }}$, P. Cochonat ${ }^{c}$, D. Levaché ${ }^{d}$, G. Sermondadaz ${ }^{d}$, M. Seranne ${ }^{b}$}

a National Oceanography Centre of Southampton (NOCS), Challenger Division for Seafloor Processes, Southampton (UK)

b Université Montpellier 2, Laboratoire Dynamique de la Lithosphère, Montpellier (France)

c IFREMER, Département Géosciences Marines, Laboratoire Environnements Sédimentaires, Brest (France).

d TOTAL, Pau (France).

* Corresponding author: Aurélien Gay, NOCS, Empress Dock, Room 786/12, SO14 3ZH Southampton, UK.

E-mail adress : ayg@noc.soton.ac.uk

\begin{abstract}
Using high quality 3D seismic data within the Lower Congo Basin (LCB), we have identified pockmarks that are aligned above the sinuous belt of a buried turbiditic palaeochannel, $1000 \mathrm{~m}$ beneath seafloor. Geochemical analyses on cores (GC traces), taken in the centre of four of these pockmarks along this channel, show no clear evidence for migrated oil. But, some features of the GC traces, including elevated baselines (UCM $>34$ $\mu \mathrm{g} / \mathrm{g}$ ) and a broad molecular weight range of n-alkanes with little odd-even preference, may be interpreted as indicating the presence of thermogenic hydrocarbons in the cores.

Seismic profiles show that these pockmarks developed above two main features representative of pore fluid escape during early compaction:

1) Closely spaced normal faults affecting the upper 0-800 msTWT of the sedimentary column. This Highly-Faulted Interval ( $\mathrm{HFI})$ appears as a hexagonal network in
\end{abstract}


plane view, which is characteristic of a volumetrical contraction of sediments in response to pore fluid escape.

2) Buried palaeo-pockmarks and their underlying chimneys seem to be rooted at the channel-levee interface. The chimneys developed during early stages of burial and are now connected to the HFI.

This study shows that the buried turbiditic channel now concentrates thermogenic fluids that can migrate through early chimneys and polygonal faults to reach the seafloor within some pockmarks. Using a multidisciplinary approach within the Lower Congo Basin, combining 3D seismic data and geochemical analyses on cores, we trace the fluid history from early compaction expelling pore fluids to later migration of thermogenic hydrocarbons.

\section{Keywords}

Pockmarks, turbiditic channels, fluid migration, polygonal faults, seismic chimneys, pipes.

\section{Introduction}

Gases of thermal origin in near-surface sediments are believed to have been generated at greater depth and migrated to the surface (Leythaeuser et al., 2000; Leythaeuser et al., 1982). Detection of near-surface thermal hydrocarbons could obviously be of economic importance because it offers the possibility of direct geochemical hydrocarbon prospecting and exploration (Wenger and Isaksen, 2002; Sassen et al., 2000; Abrams, 1992; Horvitz and Ma, 1988; Faber and Stahl, 1984; Horvitz, 1972, 1978). The origin of hydrocarbons in shallow sediments and the applicability of geochemical surface data in petroleum prospecting is still controversial due to difficulties in data interpretation and in the principal understanding of the effects of biodegradation and vertical migration of hydrocarbons from deep source rocks to the surface (Faber et al., 1998; Hunt, 1990; Fuex, 1977).

Due to the low matrix permeability of argillaceous mudstone, fluid flow through the sedimentary column is quite slow and diffusive but it is compensated for by Ma timescale. 


\section{Marine and Petroleum Geology - In Press 2006}

However, active gas venting is clearly controlled by subsurface structures such as faults and faulted anticlines (Eichhubl et al., 2000). Evidence of focused fluid flow through the sedimentary column is seen 1) on surface by pockmarks that are consistently located above faults of a polygonal fault interval (Gay et al., 2004) and 2) in the sedimentary column by seismic chimneys that are indicative of deeper reservoirs (Gay et al., 2003; Heggland, 1998). Seeps associated with diapiric features in offshore West Africa are often abundant and are often very large (visibly oil-stained sediments, very high petroleum concentrations) and actively migrating, associated with high concentrations of gas with a thermogenic component and sometimes supporting oil slicks on the sea surface (Wenger and Isaksen, 2002). Even when seeps are authenticated, their presence does not prove economic hydrocarbon accumulations at depth, seal failure or gas displacement from reservoirs (Wenger and Isaksen, 2002). In the Lower Congo Basin (LCB), we have identified pockmarks related to a deep buried turbiditic channel (i.e. upper Miocene). Using a multidisciplinary approach, combining 3D seismic data and geochemical analyses on shallow sediments (Fig. 1), we trace the fluid history from early compaction expelling pore fluids to later migrations of deep thermogenic hydrocarbons from the upper Miocene turbiditic channel. Although our examples are specific to the LCB, it is hoped that the dynamical model proposed may find applicability in other basins characterized by similar post-rift stratigraphy.

\section{Data base, sample selection and analyses}

This study was primarily based on 3D seismic datasets from the Lower Congo Basin (LCB) acquired by the TOTAL oil company (Fig. 1). The selected 3D-dataset covers an area of 4150 square kilometers with a line spacing of $12,5 \mathrm{~m}$, a CDP distance of $12,5 \mathrm{~m}$ and a vertical resolution of $4 \mathrm{~ms}$. The data were loaded on a workstation and interpreted using the SISMAGE software developed by TOTAL. The bathymetric and reflectivity maps were acquired with a Simrad EM12 dual multibeam. Complementary data have been collected more recently with the Simrad EM300 dual multibeam and provided higher vertical and lateral resolution for acquisition in water depth less than $3500 \mathrm{~m}$. Data from the ODP Leg 175 on the West African margin (see Fig. 1 for location) have constrained stratigraphy record, 
sedimentation rates and mechanical properties of Pliocene to Recent sediments (Wefer et al., 1998a).

Core locations were chosen on the basis of strong evidence of gas on seismic profiles (seismic chimney above a BSR (Bottom Simulating Reflector) and a free gas zone) and indications of actual seepage processes (i.e. pockmark) on the seafloor identified on 3D seismic data and on reflectivity maps (Cores $\mathrm{Ca}, \mathrm{Cb}, \mathrm{Cc}$ and $\mathrm{Cd}$ on Fig. 3) between 1300 and $1700 \mathrm{~m}$ water depth. Headspace gas concentrations (C1-C7) were measured on all sections of cores with a GC-FID chromatography system. The gases were resolved into separate peaks which are quantified in ppm compared to a previously calibrated standard. The samples were oven dried $\left(40^{\circ} \mathrm{C}\right)$ and soxhlet extracted with n-hexane. The total extract was reduced in volume. An aliquot of each sample is then scanned by fluorometer to determine the maximum emission intensity with a Perkin-Elmer LS50B Fluorometer. For the GC15+ and GC-MS analysis, hydrocarbon fractions were injected onto a chromatography system. The mixture is resolved into separate peaks with an Unresolved Complex Mixture (UCM): three internal standards (heptamethylnonane, chloro-octadecane and squalane) are added to calibrate the peaks and UCM response. Another aliquot is injected onto a capillary gas chromatograph (HP 6890 Series GC System) fitted with a flame ionisation detector through a split inlet with electronic pressure control.

Several methods can be used to determine the sources of gaseous and liquid hydrocarbon, such as the gas composition (ratio of $\mathrm{C} 1 / \mathrm{C} 2$ ), the maximum intensity of TSF, GC and GC-MS (mass-spectrometry) analyses and the carbon isotopic ratio of $\mathrm{C} 1$ (Prinzhofer et al., 2000; Abrams, 1996; Kastner et al., 1995; Saunders et al., 1993; Brooks et al., 1983; Reitsema, 1978). Results are reported in the Table 1.

\section{Geological settings}

The Lower Congo Basin is one of the numerous sub-basins that develop during the opening of the West African passive margin at early Cretaceous (130 ma) (Marton et al., 2000; Jansen et al., 1984). Following the deposition of thick evaporites during mid-Aptian 
time (Karner et al., 1997), two superposed intervals took place from late Cretaceous to present (Seranne et al., 1992) (Fig. 2):

1) From Late Cretaceous to early Oligocene: this period is characterized by lowamplitude/low-frequency sea-level changes and an even climate (greenhouse period) (Seranne, 1999). These eustatic and climatic conditions have led to the deposition of an aggradational carbonate/siliciclastic ramp. This interval is characterized by lacustrine and marine source rocks producing thermogenic oils and gases (Burwood, 1999) (Fig. 2).

2) From early Oligocene to Pliocene: the major change in oceanic circulation has led to the formation of an ice cap. The environmental conditions are characterized by high-amplitude/high-frequency eustatic variations and an alternating drier and wetter climate (ice-house period) (Seranne, 1999). The sedimentation is dominated by the progradation of a terrigenous wedge that has led to the formation of the large turbiditic fan off Congo and Angola slope (Droz et al., 1996; Uchupi, 1992; Brice et al., 1982). This fan is mainly composed of turbiditic palaeo-channels (Oligo-Miocene interval). Thermogenic fluids migrating upward are preferentially trapped into these silty-sandy channels, playing the role of reservoirs (Burwood, 1999) (Fig. 2). Further south, turbidite sands are commonly associated with 3 major depositional sequences in the Block 4 within the Angola basin (Anderson et al., 2000): the 17.515.5 Ma sequence (Burdigalian, early Miocene), the 8.2-6.3 Ma sequence (Tortonian, Late Miocene), and the 6.3-5.5 Ma sequence (Messinian, Late Miocene).

3) From early Pliocene time to Present: the shelf and the slope are deeply incised by a canyon that directly connects the Congo River with the basin floor. Analyses conducted during the ODP Leg 175 have shown that turbidity currents played a minimal role in transporting sediment within the Lower Congo Basin (Pufahl et al., 1998; Giraudeau et al., 1998). Coarse sediments trapped into the canyon were carried far onto the lower fan (Savoye et al., 2000; Uenzelmann-Neben, 1998; Jansen et al., 1984) while only muddy sediments are deposited on the slope 


\section{Marine and Petroleum Geology - In Press 2006}

(Cooper, 1999; Wefer et al., 1998b) and mixed with hemipelagic sediments. The

Pliocene-Present interval is considered as a good seal above the OligoceneMiocene turbiditic interval (Fig. 2) (Burwood, 1999).

One of the main tectonic features of the West African margin is the gravitational sliding of post-rift sediments above a décollement layer made up of Aptian evaporites ( Liro and Cohen, 1995; Duval et al., 1992; Lundin, 1992). In the Lower Congo Basin, gravitational processes created two structural domains each about $100 \mathrm{~km}$ wide: an extensional domain on the upper slope and a compressive domain located downslope (Fig. 2). The extensional domain is locally associated with large amounts of extension across listric faults creating individual rafts and grabens (Rouby et al., 2002; Duval et al., 1992; Burollet, 1975).

\section{Organization of seafloor pockmarks}

In the southern part of the study area the seafloor is characterized by small circular pockmarks, ranging from $100 \mathrm{~m}$ to $300 \mathrm{~m}$ in diameter, and from a few meters to a maximum of $20 \mathrm{~m}$ in depth (Fig. 3). These pockmarks appear as small patches on the reflectivity map. This could be due to the presence of carbonate concretions and chemosynthetic communities within the depression (Gay et al., in press). Although pockmarks seem unorganized, they are aligned along a band, $5-10 \mathrm{~km}$ wide, that is oriented E-W (Fig. 3). The seismic profile CD across a pockmark (Core Ca location) displays two superimposed acoustic anomalies, vertically elongated under the pockmark (Fig. 4). The shallowest anomaly is ovoid in shape with depressed high-amplitude reflectors interpreted as a reduction in seismic velocities (pull-down effects) through a gas-charged column. Such acoustic anomalies are also called seismic chimneys, and could be indicative of fluid flow from deeper levels (Tingdahl et al., 2001; Hempel et al., 1994) and of deeper reservoirs (Heggland, 1998). The deepest anomaly characterized by acoustic turbidity corresponds to an inverted cone shape, marked by a fadeout of the reflectors. On both sides of this region the bright reflectors shift upward. Profile CD (Fig. 4) shows a high-amplitude reflection parallel to the seafloor located at $250 \mathrm{~ms}$ TWT. This is a Bottom Simulating Reflector (BSR), which is often considered as the lower thermodynamic limit of the gas hydrates stability zone 


\section{Marine and Petroleum Geology - In Press 2006}

(Shipley et al., 1979). BSR's are characterized by the reversed polarity compared to the seafloor reflection, indicating a downward reduction of seismic impedance and therefore of seismic velocity. This contrast in impedance is probably due to the presence of free gas entrapped below the gas hydrate stability zone, and the BSR can be considered as the interface between high-velocity gas hydrates and the underlying gas-charged sediments of low acoustic velocity. On this profile, the BSR is deflected upward directly beneath the pockmark depressions, suggesting a localized positive heatflow anomaly. This dome-shaped anomaly could be due to an ascending movement of fluids through the sedimentary column (De Batist et al., 2002). The seismic chimney seems to take root on the top of apper Miocene turbiditic palaeochannel. This channel appear on the seismic as high-amplitude packages with strongly scoured/erosional bases indicating deposition in a largely channelized environment.

\section{Cartography of the upper Miocene turbiditic channel}

Due to the discontinuous character of turbiditic channels infills, an automatic picking of sand bodies is difficult within these intervals. Based on the amplitude of reflectors and their continuity, the SISMAGE software developed by TOTAL allows the calculation of the "Chaotism" amplitude from a 3D seismic block. In the new 3D-Chaotism block, the upper Miocene turbiditic channels exhibit a variety of forms including high sinuosity channels with well-developed levee systems or relatively straight features in map view (Fig. 5). Depositional processes are believed to have been responsible for the dominantly linear shape and channelized cross-sectional geometry of reservoirs. The dominant orientation of turbiditic channels corresponds to the direction of the sediment supply issued from the Zaire River mouth and is related to the progradation of the Zaire fan pro-delta across the study area.

Figure 5 shows aligned pockmarks that are consistently located above the upper Miocene turbiditic channel. This observation suggests that fluids are originating from the underlying channel and are driven through seismic chimneys. However, the Pliocene-Present interval is considered to play the role of a seal cover, mainly because of its fine-grained content. This interval is affected by a large number of polygonal faults acting as a major 


\section{Marine and Petroleum Geology - In Press 2006}

process for driving up fluids entrapped within underlying sandy reservoirs (Gay et al., 2004; Lonergan et al., 2000). We consider that the polygonal fault interval may compromise the seal capacity of the Pliocene-present sedimentary cover.

\section{Role of polygonal faults}

The representative seismic section EF (Fig. 6) shows the seismic expression of a polygonal fault interval in the first $0-800$ msTWT below seafloor. It is characterized by numerous closely spaced normal faults, which have small offsets $(5-30 \mathrm{~m})$ and an average spacing (100-500 m) (Gay et al., 2004). A dip map of a horizon located in the northern part of the study area discloses a dense fault network with polygonal pattern in plane view (Fig. 6). The polygons size ranges from $1 \mathrm{~km}$ to $3 \mathrm{~km}$ and they share their edges with the adjacent polygons. Since the first recognition of a polygonal fault system in the Leper Clay of Belgium (Henriet et al., 1991), numerous examples of layer-bound polygonal fault systems have been described worldwide from 3D seismic data (Cartwright and Dewhurst, 1998; Lonergan et al., 1998; Cartwright and Lonergan, 1997; Oldham and Gibbins, 1995; Cartwright, 1994; Poag et al., 1987; Klitgord and Grow, 1980). It thus appears that lithology plays a key role in the development and in the inhomogeneous frequency of faults (Dewhurst et al., 1999a,b). Faulted intervals are now interpreted as a layer-parallel volumetric contraction of fine-grained sediments leading to the pore fluids escape (Cartwright and Lonergan, 1996). It thus appear that polygonal faulting starts at the water-sediment interface, suggesting that expulsion of fluids is initiated as sediments are still unconsolidated (Gay et al., 2004).

\section{Early formation of conduits}

The seismic profile GH (Fig. 7) across a pockmark (Core Cb location) shows two seismic chimneys branching on both sides of an upper Miocene channel (see Fig. 3 for location). Their bases are located at the channel-levee interface, where they seem to take root because of the lack of any deeper seismic anomaly. At about $250 \mathrm{~m}$ above the turbiditic channel, the seismic chimneys end abruptly at the same time: they are covered by circular depressions corresponding to palaeo-pockmarks, now sealed by muddy Mid-Pliocene to 
Present sediments. As previously described for the Pleistocene shallow buried channel on the right flank of the Zaire Canyon, the sediment overburden may stop the fluid escape and seal the pockmarks if it exceeds 240 m (Gay et al., 2003). This could indicate the synsedimentary escape of pore-fluids during the deposition of sediments over the upper Miocene channel. The development of a pockmark on the seafloor clearly indicates that fluid escape continued after the lock of palaeo-pockmarks and fluids have migrated mainly through the polygonal fault interval.

\section{Geochemical analyses on cores within isolated pockmarks}

In addition to possible biodegradation in the reservoir, hydrocarbons are known to be oxidized by bacteria in the first $10 \mathrm{~m}$ below seafloor, in the aerobic zone and in the sulfatereducing interval (Wenger and Isaksen, 2002; Devol and Ahmed, 1981; Bernard et al., 1978; Claypool and Kaplan, 1974). It is thus important to understand the processes controlling the distribution of migrated and in situ hydrocarbons in surficial sediments to detect anomalous migrated hydrocarbons. A number of geochemical signatures can be expected including that of a biogenic gas (including background gas), a migrated thermogenic gas or a mixed biogenic-thermogenic.

More than 150 gravity cores were collected on the whole Congo-Angola Basin by TOTAL. Four of these cores $(\mathrm{Ca}, \mathrm{Cb}, \mathrm{Cc}$, and $\mathrm{Cd})$ were taken within pockmarks in the study area. They are located above the upper Miocene channel at different position along the channel axis (Fig. 8). These cores were chosen on the basis of actual/recent fluid seepage evidences (underlying seismic chimney, hydrogen sulfide odor when opening cores, carbonate concretions within the core).

Core $\mathrm{Ca}$ is characterized by a medium grey clay containing carbonate concretions. The number of concretions increases with depth. The core exhibited a strong sulfide odor when opened. The sediments within core $\mathrm{Cb}$ are reddish brown very soft clays overlying dark greenish grey clays with numerous cemented sediment nodules up to $3 \mathrm{~cm}$ across. The sediments exhibit a strong hydrogen sulfide odor. Core $\mathrm{Cc}$ is composed of very soft dark greenish grey pure clays with occasional sand sized particles in the upper sections 
of the core. Core Cd corresponds to reddish brown very soft clays overlying very soft clays with occasional sand sized particles.

Geochemical analyzes conducted on cores (Table 1) show that extract yields and fluorescence intensities are relatively high $(4000<$ Imax TSF <21000) compared to other cores from the Congo-Angola Basins ( $<1000$, courtesy of TOTAL). The GC traces showed no clear evidence for migrated oil but abundant evidence for recent organic material, which tend to mask evidences of thermogenic migrated hydrocarbons on chromatograms (Fig. 8). But, some features of the GC traces, including elevated baselines (UCM $>20 \mu \mathrm{g} / \mathrm{g}$ ) and a broad molecular weight range of n-alkanes with little odd-even preference (Fig. 8), could be interpreted as indicating the presence of thermogenic hydrocarbons in the core.

Headspace analysis of $\mathrm{C} 1-\mathrm{C} 7$ (Table 1 ) show that the cores $\mathrm{Ca}$ and $\mathrm{Cb}$ have high methane (C1) content and their isotopic analyses show a value of $\delta^{13} \mathrm{C}=-70 \%$ for $\mathrm{Ca}$ and $-86 \%$ for $\mathrm{Cb}$ (relative to PDB). Abundance ratios, heavier than $-20 \%$ o to $-50 \%$ are believed to be of thermal origin and ratios lower than $-70 \%$ are considered to be biogenic in origin (Brooks et al., 1984; Tissot and Welte, 1984). The isotopic values of cores $\mathrm{Ca}$ and $\mathrm{Cb}$ should be interpreted as biogenic gases. In order to complete geochemical interpretation of the hydrocarbons (liquid fraction), extracts were selected for GC-MS analysis. They contained clearly recognizable oil finger prints. This has been interpreted as most likely derived from a marine Tertiary siliciclastic source rock with land plant input (Courtesy of TOTAL). The molecular ratios of aromatic compounds analyzed by GC-MS are consistent with a mature source rock. The use of a complete geochemical analysis shows that fluids reaching the seabed can be interpreted as a mix of biogenic and thermogenic gases.

\section{Discussion}

In the area of isolated pockmarks, there is a close relationship between pockmarks, underlying chimneys, upward deflection of the BSR (if present) and an upper Miocene turbiditic channel. In the Lower Congo Basin, turbidite sands are associated with three main stages of deposition (Anderson et al., 2000): Burdigalian (17.5-15.5 Ma), Tortonian (8.2-6.3 Ma) and Messinian (6.3-5.5 Ma). The stacking patterns of the upper 
Miocene channels comprise fine to medium grained massive sands overlain by a fining upwards package interpreted as a channel abandonment facies or as overbanks to an adjacent channel (Anderson et al., 2000). The massive sands often form the basal units of sequences that grade upwards into a succession of horizontally laminated fine sands and silts, overlain by wavy, lenticular bedded silts and interbedded muds. Due to the high porosity of silts and sands within the channel infill, the upper Miocene channel may concentrate thermogenic fluids migrating from underlying source rocks. Syn-depositional major faults located above turbiditic sand bodies may periodically act as main vertical fluid escape pathways (Lonergan et al., 2000). However, the main problem is the ability of fluids to migrate through the impermeable Pliocene-Present cover. A detailed observation of seismic profile has shown that fluids may migrate through a polygonal fault interval that developed during early stages of compaction (Gay et al., 2004). A study of the organisation of faults shows that the pockmarks are consistently located at the intersection of three neighbouring hexagons (Gay et al., 2004). The triple-junction of three neighbouring hexagonal cells represents a preferential pathway for upward fluid migration from deeper levels. Consequently, the polygonal fault interval represents an interval with a high drainage potential for pore fluids. In this context, the fluids migrating from deeper levels are preferentially driven through this interval along the pre-existing faults, which affect all of the polygonal fault interval. Faults commonly are considered conduits through which hydrocarbons move in their vertical migration from the source rock into shallower reservoirs. Faults can act either as permeable conduits for the vertical channelized flow of hydrocarbons (Hooper et al., 2002) or, over time, can bring permeable beds into contact with another and allow hydrocarbons to spill across sand-on-sand contacts (Allan, 1989). Geochemical analysis conducted on cores $\mathrm{Ca}$ and $\mathrm{Cb}$ within shallow sediments of pockmarks over the upper Miocene channel show strong evidences of a mix of biogenic methane and thermogenic fluids (methane and heavier hydrocarbons). The presence of thermogenic fluid within shallow sediments of cores $\mathrm{Ca}$ and $\mathrm{Cb}$ represents an evidence of thermogenic fluid 
migration from the reservoir (i.e. the upper Miocene channel) up to the seafloor through the polygonal fault interval.

A dynamic model is proposed for the LCB, which takes into account both kinds of sedimentation, turbiditic sedimentation building channel-levee systems on the slope and a hemipelagic sedimentation, which tends to seal the first one (Fig. 9):

1) During the Late Miocene: turbiditic channel-levee systems developed on the slope. Possibly as a result of landward avulsion, another channel-levee system is building up on the slope and the turbiditic channel is abandoned.

2) During the early Pliocene: there is slope incision by the Zaire Canyon. Coarse sediments are carried far onto the basin, starving the shelf. Only fine material, not confined into the canyon, is delivered to the Congo slope. This suspended terrigenous material is mixed with hemipelagic sediments to feed a thick progradational wedge that overlays abandoned turbiditic sandy-channels. As the sediment thickness over these buried palaeochannels ranges between $130 \mathrm{~m}$ and $240 \mathrm{~m}$, pore fluids continue to escape and pockmarks develops on the seafloor.

3) During the Mid-Pliocene: sediment thickness over the channel reaches $240 \mathrm{~m}$ or more. The fine-grained sedimentation on the slope can act as a seal and the fluid migration stops.

4) From the Mid-Pliocene to the Present: during the early compaction of overlying mud-dominated sediments, pore fluids are expelled and numerous hexagonal small-scale faults are initiated. The triple-junction of three neighbouring hexagonal cells represents a preferential pathway for fluid migration from deeper levels, in particular thermogenic gazes or oils, leading to the formation of pockmarks on seafloor.

However, seismic profile CD (Fig. 4) shows that deep thermogenic fluids can not use early chimneys if hydrates are present on the section. In this case, fluids migrating from the upper Miocene channel can accumulate under the hydrate stability zone to form a thick layer of free gas. The main factor controlling fluid entrapment is the presence of impermeable layers of hydrates, 150 to $200 \mathrm{~m}$ thick below seafloor, leading to the generation of excess 
pore fluid pressure in the underlying free gas accumulation. The free gas can escape up to the seafloor along faults of the polygonal fault interval. This system might follow the faultvalve behaviour developed by Sibson (1992) and fluids could escape periodically. Such cycling should be recorded within this kind of pockmarks (mineralogy and/or biology) and need further sampling and study.

\section{Conclusion}

This detailed study of pockmarks within the Lower Congo Basin shows that the fluid migration history is complex due to the inter-relation of tectonic features and sedimentary bodies. We have shown that seafloor pockmarks which seem isolated are most often related to an underlying upper Miocene turbiditic channel. Geochemical analyzes conducted on four cores taken within pockmarks have led to the conclusion that fluids that are expelled on the present-day seafloor are a mix of biogenic and thermogenic gases and oil. This observation suggests that the upper Miocene channel plays the role of a reservoir for thermogenic fluids originating from underlying cretaceous source rocks.

However, two kinds of pore fluid escape during early stages of compaction (0$600 \mathrm{~m}$ ) have been identified: 1) chimneys that formed on both edges of a buried turbiditic channel and 2) a polygonal fault interval due to the volumetrical contraction of mud-rich sediments starting at the water-sediment interface. The identification of seafloor pockmarks related to an underlying upper Miocene channel and associated to a mix of biogenic and thermogenic fluids shows that these shallow conduits can be re-used at deeper depth by thermogenic fluids questioning the seal capacity of the mud-dominated sedimentary cover.

Evidences for a hydrocarbon generating system in a basin needs a comprehensive approach. Geochemical sampling locations should be selected at favorable sites for hydrocarbon migration based on geophysical data and a good understanding of local geology. The evidence for an oil charge in sediments of the Lower Congo Basin would be fairly tenuous if based on only geochemical analyzes. When taken geophysical and geochemical evidences together, confidence in the interpretation increases, and the evidence for a widespread continuous hydrocarbon migration becomes more compelling. 


\section{Marine and Petroleum Geology - In Press 2006}

This study illustrates the fact that the sedimentary fluid migration is a continuous process during the burial story of sediments, starting at the sediment-water interface (escape of pore fluids and/or biogenic fluids) and continuing during compaction and lithification (thermogenic fluids).

\section{Acknowledgements}

The authors would like to express their gratitude to TOTAL for their financial support and data supplies and for supporting the publication of this work. We gratefully acknowledge the IFREMER

\section{References}

Abrams, M. A., (1992). Geophysical and geochemical evidence for subsurface hydrocarbon leakage in the Bering Sea, Alaska. Marine and Petroleum Geology Bulletin, 9, 208221

Abrams, M. A., (1996). Distribution of subsurface hydrocarbon seepage in near-surface marine sediments. In: D. Schumacher and M. A. Abrams, Hydrocarbon Migration and its near-surface expression. AAPG Memoir, 66, 1-14.

Allan, U. S., (1989). Model for hydrocarbon migration and entrapment within faulted structures. AAPG bulletin, 73, 803-811

Anderson, J. E., Cartwright, J., Drysdall, S. J. \& Vivian, N., (2000). Controls on turbidite sand deposition during gravity-driven extension of a passive margin: examples from Miocene sediments in Block 4, Angola. Marine and Petroleum Geology, 17, 11651203

Bernard, B. B., Brooks, J. M. \& Sackett, W. M., (1978). Light hydrocarbons in recent continental shelf and slope sediments. Journal of Geophysical Research, 83, 40534061

Brice, S. E., Cochran, M. D., Pardo, G. \& Edwards, A. D., (1982). Tectonics and Sedimentation of the South Atlantic Rift Sequence: Cabinda, Angola. In: W. a. Drake, Studies in Continental Margin Geology. AAPG, Memoir 34, 5-18. 
Brooks, J. M., Kennicutt II, M. C., Bernard, L. A., Genoux, G. J. \& Carey, B. D., (1983). Applications of total scanning fluorescence to exploration geochemistry. Offshore Technology Paper, OTC-4624, 393-400

Brooks, J. M., Kennicutt, M. C., Fay, R. R. \& McDonald, T. J., (1984). Thermogenic gas hydrates in the Gulf of Mexico. Science, Vol. 225, p. 409-411.

Burollet, P. F., 1975, Tectonique en radeaux en Angola: Bulletin de la Société Géologique de France, v. XXII, p. 503-504.

Burwood, R., (1999). Angola: source rock control for Lower Congo Coastal and Kwanza Basin petroleum systems. In: N. R. Cameron, R. H. Bate and V. S. Clure, The Oil and Gas Habitats of the South Atlantic. Geological Society of London, 153, London, 181-184.

Cartwright, J. \& Lonergan, L., (1996). Volumetric contraction during the compaction of mudrocks: a mechanism for the development of regional-scale polygonal fault systems. Basin Research, 8, 183-193

Cartwright, J. A., (1994). Episodic basin-wide fluid expulsion from geopressured shale sequences in the North Sea basin. Geology, 22, 447-450

Cartwright, J. A. \& Lonergan, L., (1997). Seismic expression of layer-bound fault systems of the Eromanga and North Sea Basins. Exploration Geophysics, 28, 23-331

Cartwright, J. A. \& Dewhurst, D. N., (1998). Layer-bound compaction faults in fine-grained sediments. Geological Society of America Bulletin, 110(10), 1242-1257

Claypool, G. E. \& Kaplan, I. R., (1974). The origin and distribution of methane in marine sediments. In: I. R. Kaplan, Natural Gases in Marine Sediments. Plenum Press, New York, 99-139.

Cooper, C. K., (1999). Ocean currents offshore Northern Angola. OTC, paper 10749

De Batist, M., J. Klekx, P. Van Rensbergen, M. Vanneste, J. Poort, A. Golmshtok, A. Kremlev, O. Khlystov, \& P. Krinitsky, 2002, Active gas-hydrate destabilization and methane venting in Lake Baikal, Siberia ?: Terra Nova, v. 14, p. 436-442. 
Devol, A. H. \& Ahmed, S. I., (1981). Are high rates of sulfate reduction associated with anaerobic oxidation of methane ? Nature, 291, 407-408

Dewhurst, D. N., Cartwright, J. \& Lonergan, L., (1999a). The development of polygonal fault systems by syneresis of colloidal sediments. Marine and Petroleum Geology, Vol. 16, p. $793-810$

Dewhurst, D. N., Cartwright, J. A. \& Lonergan, L., (1999b). Three-dimensional consolidation of clay-rich sediments. Canadian Geotechnical Journal, Vol. 36(No. 2), p. 355-362

Droz, L., Rigaut, F., Cochonat, P. \& Tofani, R., (1996). Morphology and recent evolution of the Zaire turbidite system (Gulf of Guinea). GSA bulletin, 108(3), 253-269

Duval, B., C. Cramez, and M. P. A. Jackson, 1992, Raft tectonics in the Kwanza basin, Angola: Marine and Petroleum Geology, v. 9, p. 389-404.

Eichhubl, P., Greene, H. G., Naehr, T. \& Maher, N., (2000). Structural control of fluid flow: offshore fluid seepage in the Santa Barbara Basin, California. Journal of Geochemical Exploration, 69/70, 545-549

Faber, E. \& Stahl, W., (1984). Geochemical surface exploration for hydrocarbons in North Sea. AAPG bulletin, 68(3), 363-386

Faber, E., Botz, R., Poggenburg, J., Schmidt, M., Stoffers, P. \& Hartmann, M., (1998). Methane in Red Sea brines. Organic Geochemistry, 29(1-3), 363-379

Fuex, A. N., (1977). The use of stable carbon isotopes in hydrocarbon exploration. Geochemical Exploration, 7, 155-188

Gay, A., Lopez, M., Cochonat, P., Sultan, N., Cauquil, E. \& Brigaud, F., (2003). Sinuous pockmark belt as indicator of a shallow buried turbiditic channel on the lower slope of the Congo Basin, West African Margin. In: P. Van Rensbergen, R. R. Hillis, A. J. Maltman and C. K. Morley, Subsurface Sediment Mobilization. Geological Society of London, Special Publications, 216, 173-189.

Gay, A., Lopez, M., Cochonat, P. \& Sermondadaz, G., (2004). Polygonal faults-furrows system related to early stages of compaction - Upper Miocene to present sediments of the Lower Congo Basin. Basin Research, 16, 101-116 
Gay, A., M. Lopez, H. Ondreas, J.-L. Charlou, P. Cochonat, and G. Sermondadaz, (in press), Seafloor features related to upward methane flux within a Giant Pockmark of the Lower Congo Basin. Marine Geology.

Giraudeau, J., Christensen, B. A., Hermelin, O., Lange, C. B., Motoyama, I. \& Shipboard Scientific Party (1998). Biostratigraphic age models and sedimentation rates along the southwest African Margin. In: G. Wefer, W. H. Berger and C. Richter, Proceedings of the Ocean Drilling Program. Initial Reports Vol. 175, 543-546.

Heggland, R., (1998). Gas seepage as an indicator of deeper prospective reservoirs. A study based on exploration 3D seismic data. Marine and Petroleum Geology, 15, 1-9

Hempel, P., Spiess, V. \& Schreiber, R., (1994). Expulsion of shallow gas in the SkagerrakEvidence from subbottom profiling, seismic, hydroacoustical and geochemical data. Estuarine, Coastal and Shelf Science, 38, 583-601

Henriet, J. P., De Batist, M. \& Verschuren, M., (1991). Early fracturing of Palaeogene clays, southernmost North Sea: Relevance to mechanisms of primary hydrocarbon migration. In: A. M. Spencer, Generation, accumulation and production of Europe's hydrocarbons. European Association of Petroleum Geologists, Special Publication Vol. 1, 217-227.

Hooper, R. J., Fitzsimmons, R. J., Grant, N. \& Vendeville, B. C., (2002). The role of deformation in controlling depositional patterns in the south-central Niger Delta, West Africa. Journal of Structural Geology, 24, 847-859

Horvitz, E. P. \& Ma, S., (1988). Hydrocarbons in near-surface sand, a geochemical survey of the Dolphin field in North Dakota. Association of Petroleum Geochemical Explorationnists Bulletin, 4(1), 30-46

Horvitz, L., (1972). Vegetation and geochemical prospecting for petroleum. AAPG bulletin, $56,925-940$

Horvitz, L., (1978). Near-surface evidence of hydrocarbon movement from depth. In: W. H. Roberts III and R. J. Cordell, Problems of petroleum migration. AAPG Studies in Geology, 10, 241-269. 
Hunt, I. M., (1990). Generation and migration of petroleum from abnormally pressured fluid compartements. AAPG bulletin, 74, 1-12

Jansen, J. H., Van Weering, T. C. E., Gieles, R. \& Van Ipresen, J., (1984). Middle and Late Quaternary oceanography and climatology of the ZAIRE-Congo fan and the adjacent eastern Angola Basin. Netherlands Journal of Sea Research, 17, 201-249

Jansen, J. H. F., Giresse, P. \& Moguedet, G., (1984). Structural and sedimentary geology of the Congo and southern Gabon continental shelf; a seismic and acoustic reflection survey. Netherlands Journal of Sea Research, 17(2-4), 364-384

Karner, G. D., Driscoll, N. W., McGinnis, J. P., Brumbaugh, W. D. \& Cameron, N. R., (1997). Tectonic significance of syn-rift sediment packages across the Gabon-Cabinda continental margin. Marine and Petroleum Geology, 14(7/8), 973-1000

Kastner, M., Sample, J. C., Whiticar, M. J., Hovland, M., Cragg, B. A. \& Parkes, J. R., (1995). Geochemical evidence for fluid flow and diagenesis at the cascadia convergent margin. In: B. Carson, G. K. Westbrook, R. J. Musgrave and E. Suess, Proceedings of the Ocean Drilling Program, Scientific Results. ODP, 146, 375-384.

Klitgord, K. D. \& Grow, J. A., (1980). Jurassic seismic stratigraphy and basement structure of the western Atlantic magnetic quiet zone. AAPG bulletin, 64, 1658-1680

Leythaeuser, D., Schaefer, R. G. \& Yukler, A., (1982). Role of diffusion in primary migration of hydrocarbons. AAPG bulletin, $66,408-429$

Leythaeuser, D., Schwark, L. \& Keuser, C., (2000). Geological conditions and geochemical effects of secondary petroleum migration and accumulation. Marine and Petroleum Geology, 17, 857-859.

Liro, L. M., \& R. Cohen, 1995, Salt deformation history and postsalt structural trends, offshore southern Gabon, west Africa, in M. P. A. Jackson, D. G. Roberts, and S. Snelson, eds., Salt tectonics: a global perspective, AAPG Memoir 65, 323-331.

Lonergan, L., N. Lee, H. D. Johnson, J. Cartwright, and R. Jolly, 2000, Remobilization and Injection in Deepwater Depositional Systems: Implications for Reservoir Architecture and Prediction: Deep-Water Reservoirs of the World, December 3-6, p. 515-532. 


\section{Marine and Petroleum Geology - In Press 2006}

Lonergan, L., Cartwright, J. \& Jolly, R., (1998). The geometry of polygonal fault systems in Tertiary mudrocks of the North Sea. Journal of Structural Geology, 20(5), 529-548.

Lundin, E. R., 1992, Thin-skinned extensional tectonics on a salt detachment, northern Kwanza basin, Angola: Marine and Petroleum Geology, v. 9, p. 405-411.

Marton, L. G., Tari, G. C. \& Lehmann, C. T., (2000). Evolution of the Angola passive Margin, West Africa, with Emphasis on Post-Salt Structural Styles. In: W. Moriak and M. Talwani, Atlantic Rifts and Continental Margins. American Geophysical Union, Washington, DC, 129-149.

Oldham, A. C. \& Gibbins, N. M., (1995). Lake Hope 3D: A case study. Exploration Geophysics, 26, 383-394

Poag, C. W., Watts, A. B. et al. (1987). Initial reports of the Deep Sea Drilling Project. 95. U.S. Government Printing Office, Washington D.C., 817 pp

Prinzhofer, A., Rocha Mello, M. \& Takaki, T., (2000). Geochemical characterization of natural gas: A physical multivariable approach and its applications in maturity and migration estimates. AAPG bulletin, 84(8), 1152-1172

Pufahl, P. K., Maslin, M. A., Anderson, L. et al. (1998). Lithostratigraphic summary for LEG 175: Angola-Benguela upwelling system. In: G. Wefer, W. H. Berger and C. Richter, Proceedings of the Ocean Drilling Program. Initial reports Vol. 175, p. 533-542.

Reitsema, R. H., (1978). Light hydrocarbon in Gulf of Mexico water: sources and relation to structural highs. Journal of Geochemical Exploration, 10, 139-151

Sassen, R., Requejo, R. \& Kennicutt II, M. C., (2000). Geochemistry of Angolan oil and rocks. In. The geochemical and Environmental Research Group Texas A\&M University and The Sociedade Nacional de Combustiveis de Angola (SONANGOL), pp.

Saunders, D. F., Burson, K. R. \& Branch, J. F., (1993). Integrated surface methods profiles, two east Texas fields. Association of Petroleum Geochemical Explorationnists Bulletin, 9, 32-50 
Savoye, B., Cochonat, P. \& al., e., (2000). Structure et évolution récente de l'éventail turbiditique du Zaire: premier résultats scientifiques des missions d'exploration Zaiango 1 et 2 (Marge Congo-Angola). Comptes-Rendus de l'Académie des Sciences de la Terre et des Planètes, 331, 211-220

Seranne, M., Seguret, M. \& Fauchier, M., (1992). Seismic super-units and post-rift evolution of the continental passive margin of southern Gabon. Bulletin de la Société Géologique de France, 163(2), 135-146

Seranne, M., (1999). Early Oligocene stratigraphic turnover on the west Africa continental margin: a signature of the Tertiary greenhouse-to-icehouse transition ? Terra Nova, $11,135-140$

Shipley, T. H., Houston, M. H., Buffler, R. T., Shaub, F. J., McMillen, K. J., Ladd, J. W. \& Worzel, J. L., (1979). Seismic evidence for widespread possible occurence of gashydrate horizons or continental slopes and rises. AAPG bulletin, 63, 2204-2213

Sibson, R. H., (1992). Implications of fault-valve behaviour for rupture nucleation and recurrence. Tectonophysics, 211, 283-293

Tingdahl, K. M., Bril, A. H. \& de Groot, P. F., (2001). Improving seismic chimney detection using directional attributes. Journal of Petroleum Science and Engineering, 29, 205211

Tissot, B. P. \& Welte, D. H., (1984). Petroleum formation and occurence. Springer, Berlin, pp Uchupi, E., (1992). Angola Basin: Geohistory and Construction of the Continental Rise. In: C. W. Poag and P. A. De Graciansky, Geologic Evolution of Atlantic Continental Rifts. Nostrand Reinhold, New York, 77-99.

Uenzelmann-Neben, G., (1998). Neogene sedimentation history of the Congo Fan. Marine and Petroleum Geology, 15, 635-650

Wefer, G., Berger, W. H. \& Richter, C., (1998a). Proceedings of the Ocean Drilling Program. Initial Reports, 175. Initial Reports, 577 pp 
Wefer, G., Berger, W. H. \& Richter, C., (1998b). Facies patterns and authigenic minerals of upwelling deposits off Southwest Africa. In, Proceedings of the Ocean Drilling Program. Initial Reports, 175, 487-504.

Wenger, L. M. \& Isaksen, G. H., (2002). Control of hydrocarbon seepage intensity on level of biodegradation in sea bottom sediments. Organic Geochemistry, 33(12), 1277-1292 


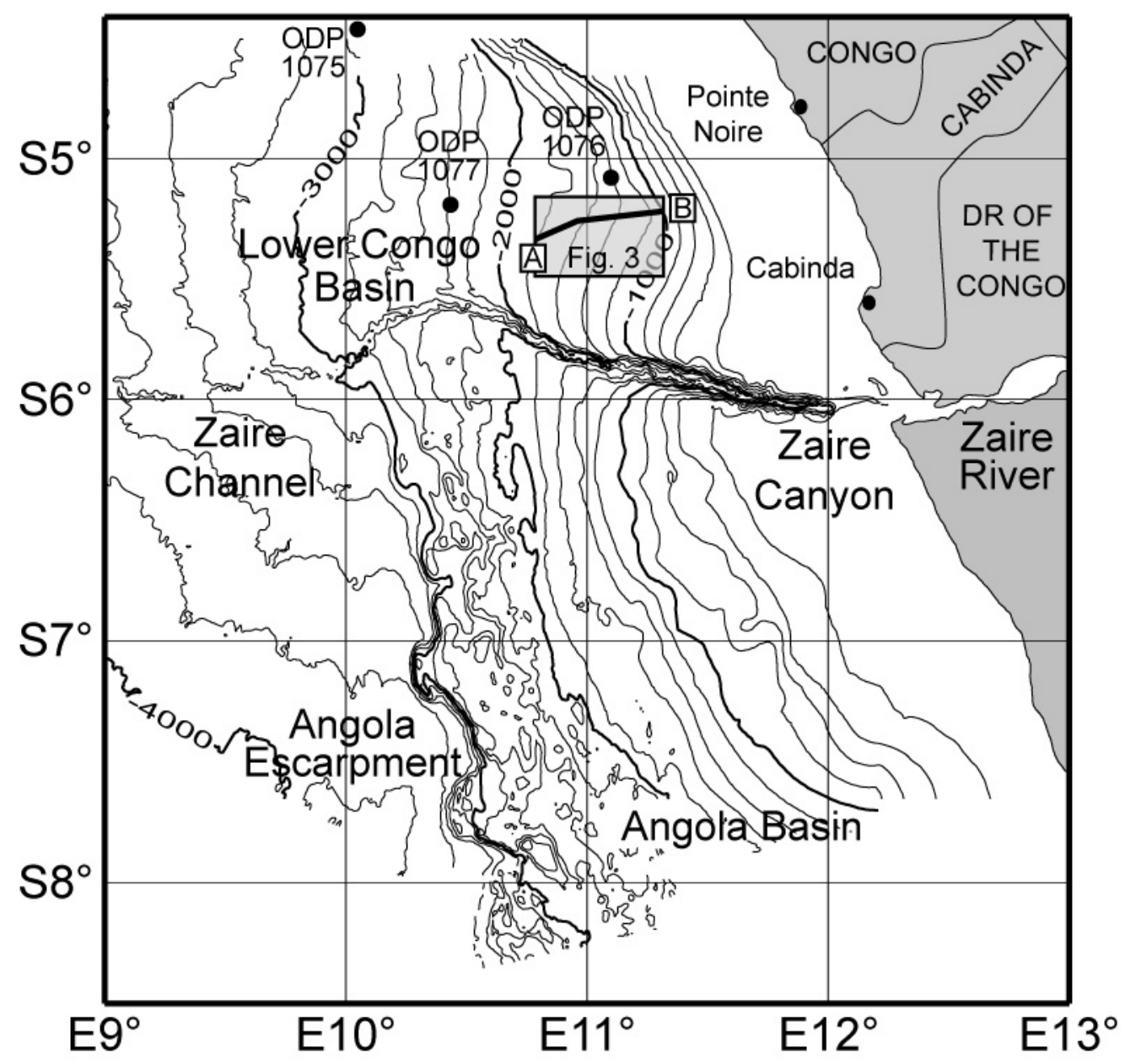

Figure 1: Bathymetric map of the Congo-Angola Basin issued from the EM-12 multibeam bathymetry acquired during the ZAIANGO project (1998-2000). The study area (grey-shaded rectangle) is located on the north flank of the present-day Zaire channel between 1000 and $1800 \mathrm{~m}$ water depth. The three sites of the Leg ODP 175 in this zone are reported. 


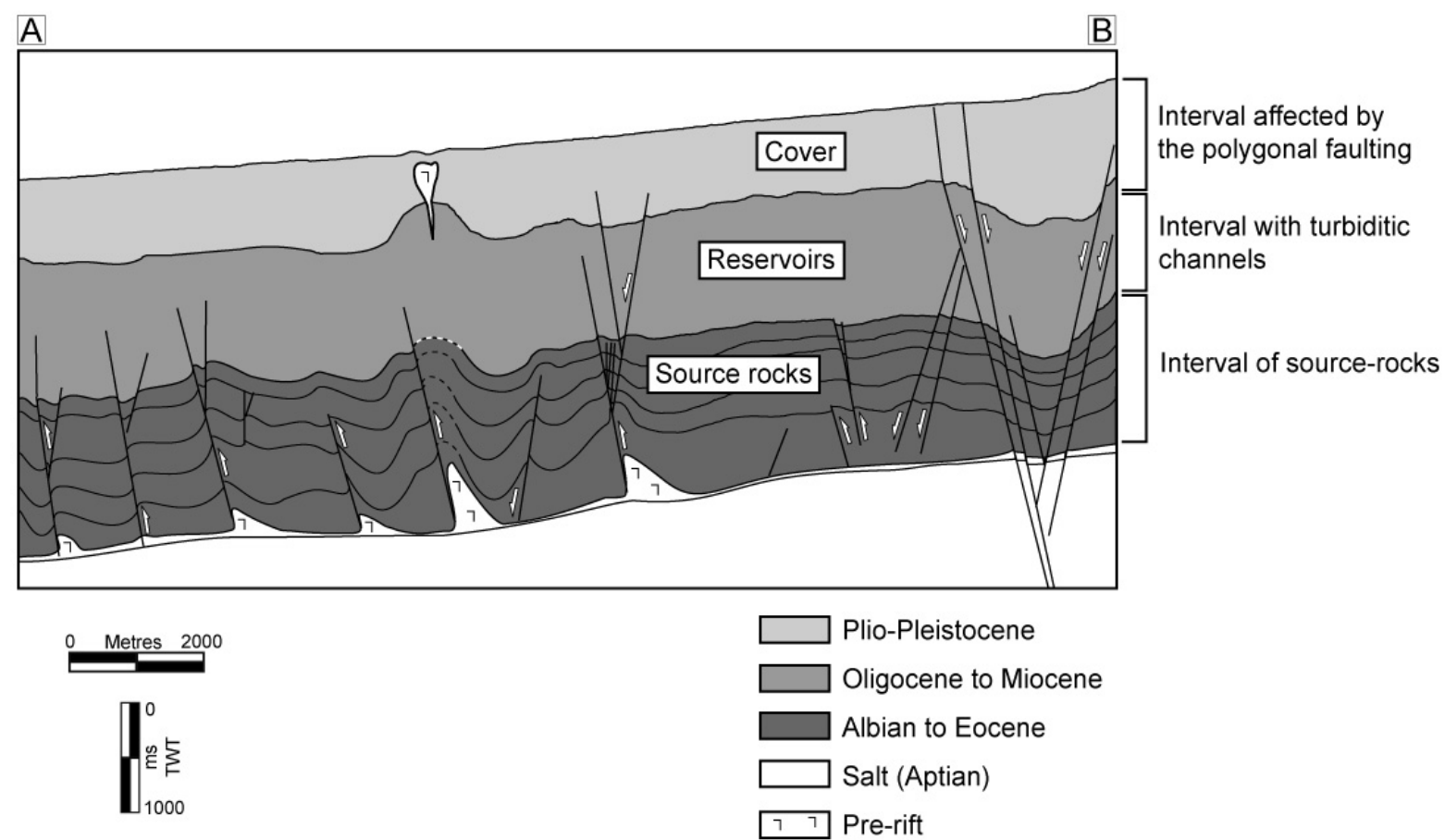

Figure 2: Line drawing of the seismic profile AB. The post-rift stratigraphy is characterized by two superposed seismic architectures: 1) an Albian to Eocene sequence containing the source rocks and 2) an Oligocene to Present sequence containing the reservoirs (turbiditic channels) and the sedimentary cover (affected by polygonal faulting). Deep thermogenic fluids migrating from the source rocks are preferentially trapped into the silty-sandy channels, playing the role of reservoirs (Burwood, 1999). 

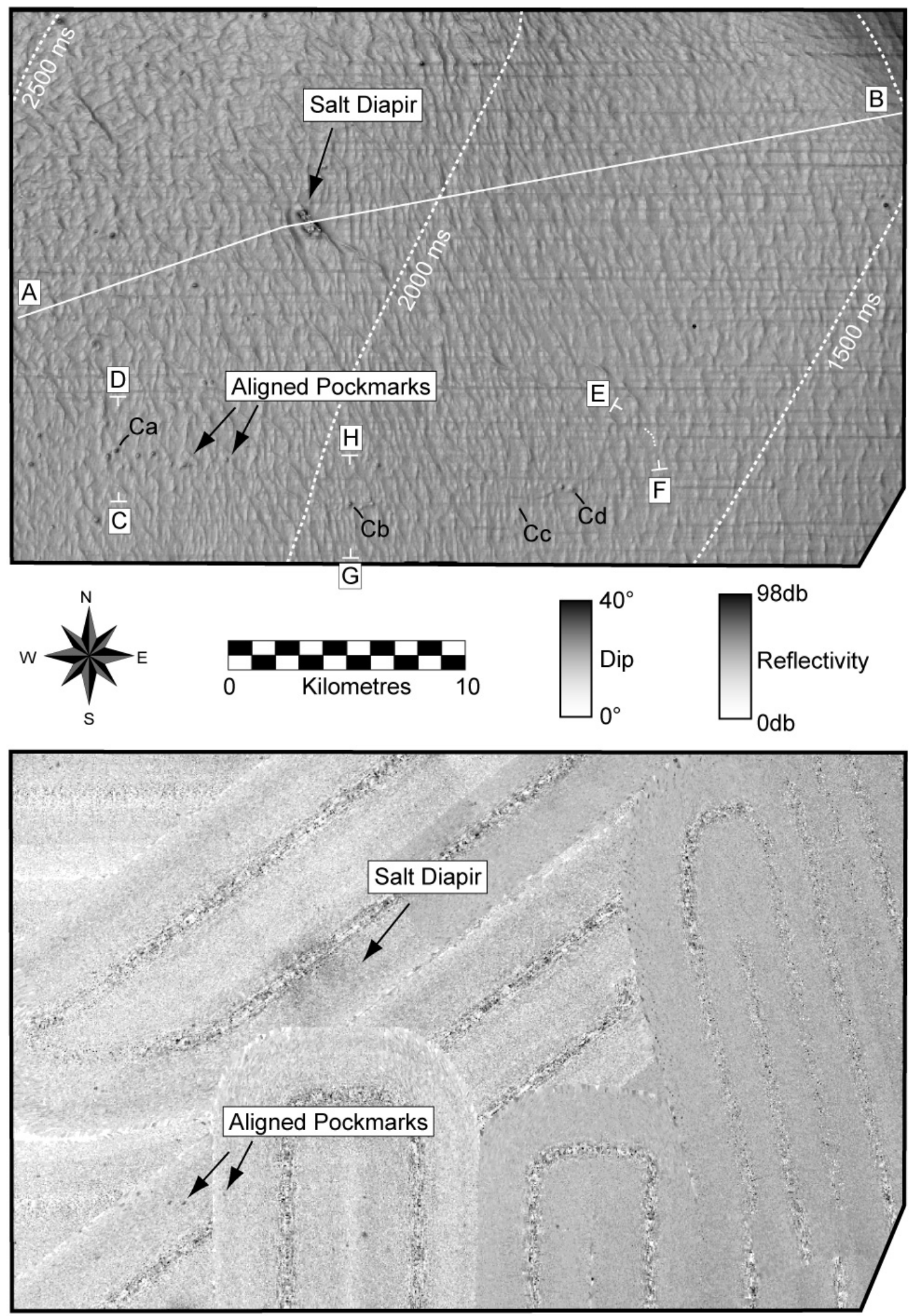

Figure 3: Up, Dip map of seafloor within the Lower Congo Basin, calculated from the 3D seismic datasets. This map shows fluid seeps evidences such as pockmarks associated with faults or salt 
Marine and Petroleum Geology - In Press 2006

diapirs. Four cores ( $\mathrm{Ca}, \mathrm{Cb}, \mathrm{Cc}$ and $\mathrm{Cd}$ ) have been taken within four different isolated pockmarks aligned along a band, 5-10 km wide, oriented E-W. Down, Reflectivity map acquired by IFREMER with a EM12 multibeam. Small dark patches represent pockmarks on the seafloor. 


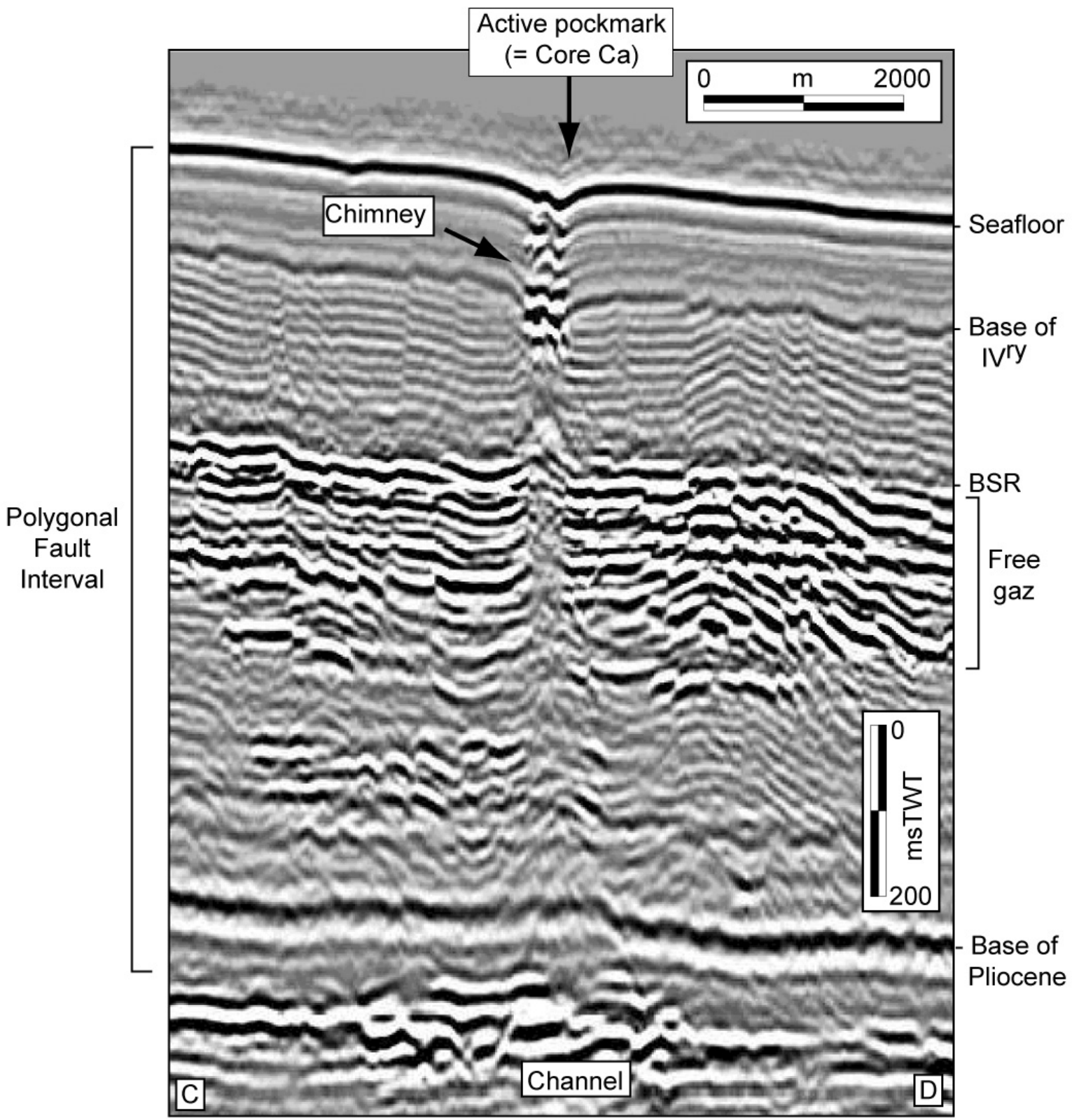

Figure 4: Seismic profile CD across a upper Miocene turbiditic channel. This profile illustrates the close relationship between an active pockmark on seafloor, an underlying seismic chimney, the upward deflected BSR, an interval with high amplitude reflectors interpreted as a free gas zone, and a deep buried (>600 m) turbiditic channel. Geochemical analyses conducted on core Ca have shown evidences of thermogenic fluids within shallow sediments. 

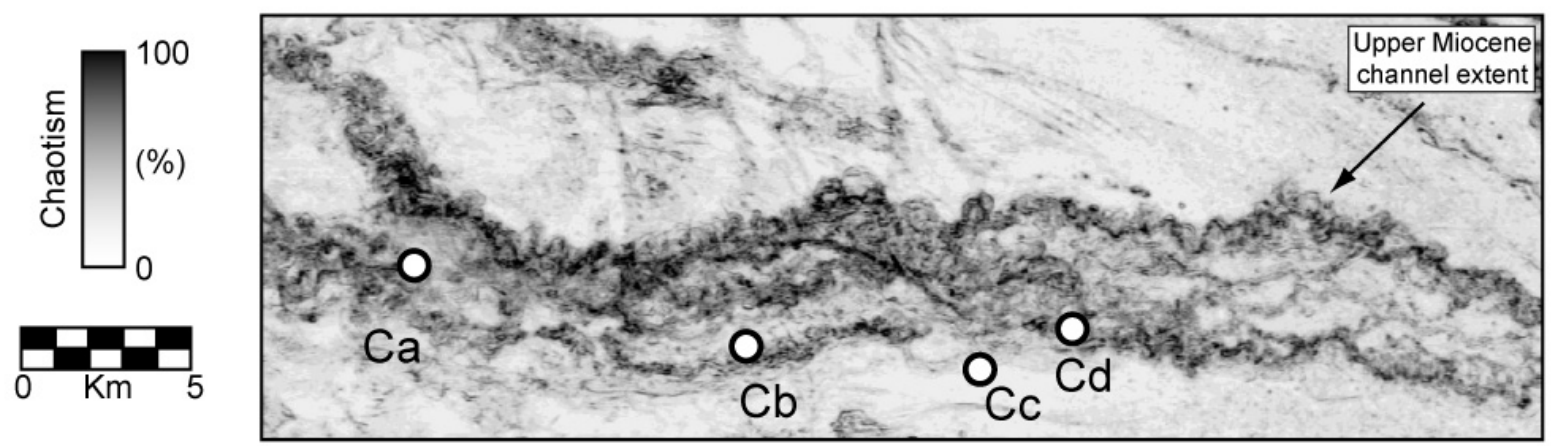

Figure 5: "Chaotism" map of the upper Miocene turbiditic channel. The seismic block has been transformed into a "Chaotism" block using the Sismage software. The average value of "Chaotism" within the upper Miocene interval is then calculated and projected on a map view. This map exhibits a variety of forms including high sinuosity channels with well-developed levee systems or relatively straight channel segments. The overall trend of the channel is E-W, which is consistent with the sediment supply from the Zaire River. Seafloor pockmarks are consistently located over the upper Miocene channel, suggesting that fluids are originating from this level. Cores Ca to Cd are reported on this map.

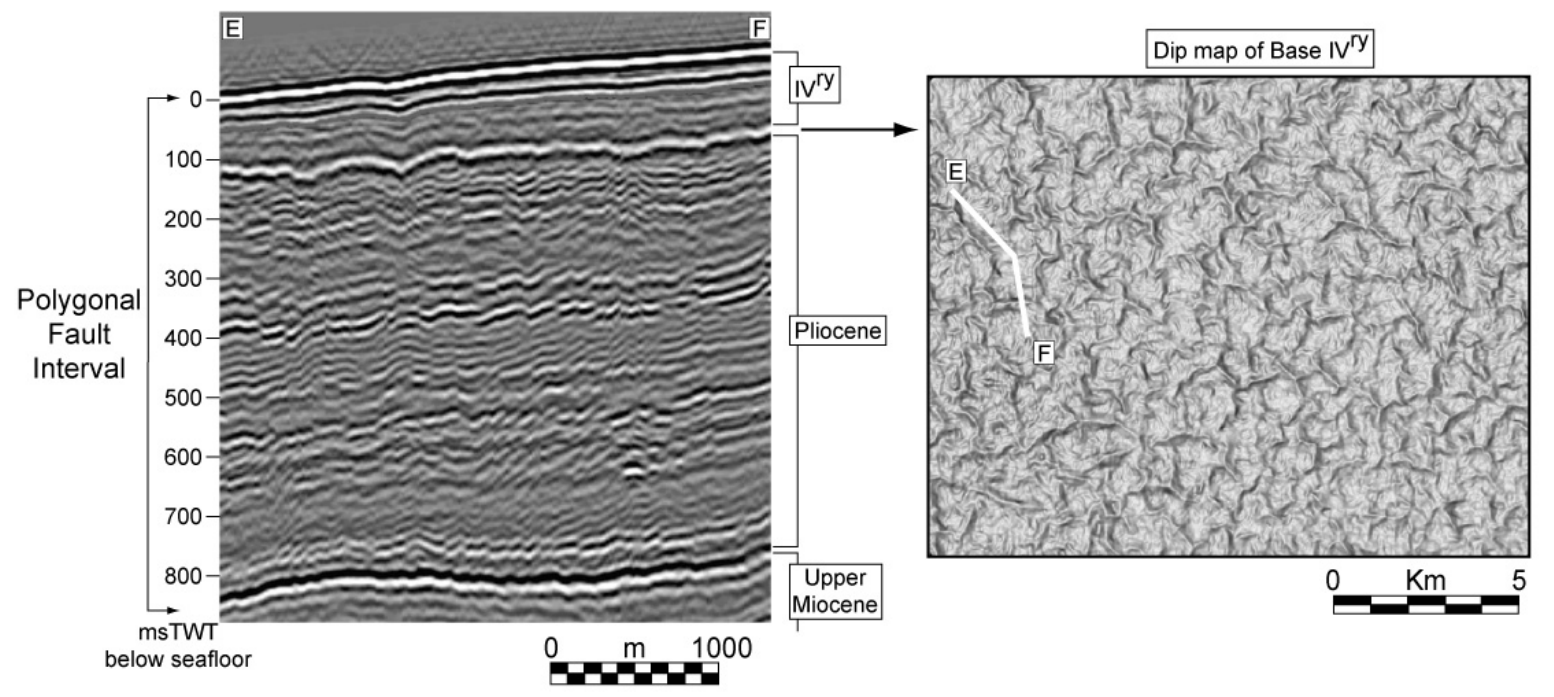

Figure 6: Left, Random seismic section EF, parallel to the main slope and perpendicular to the polygonal faults. This profile exhibits the seismic facies of a polygonal fault interval reaching the present day seafloor in the Lower Congo Basin. It is characterized by numerous closely spaced (100$500 \mathrm{~m}$ ) normal faults affecting the first $0-600 \mathrm{~m}$ of the sedimentary column. Right, Detailed dip map of 


\section{Marine and Petroleum Geology - In Press 2006}

base Quaternary within the polygonal fault interval. This map highlights the polygonal pattern of faults in plane view. The formation of polygonal faulting may be due to the volumetrical contraction of finegrained sediments during early stages of compaction. 


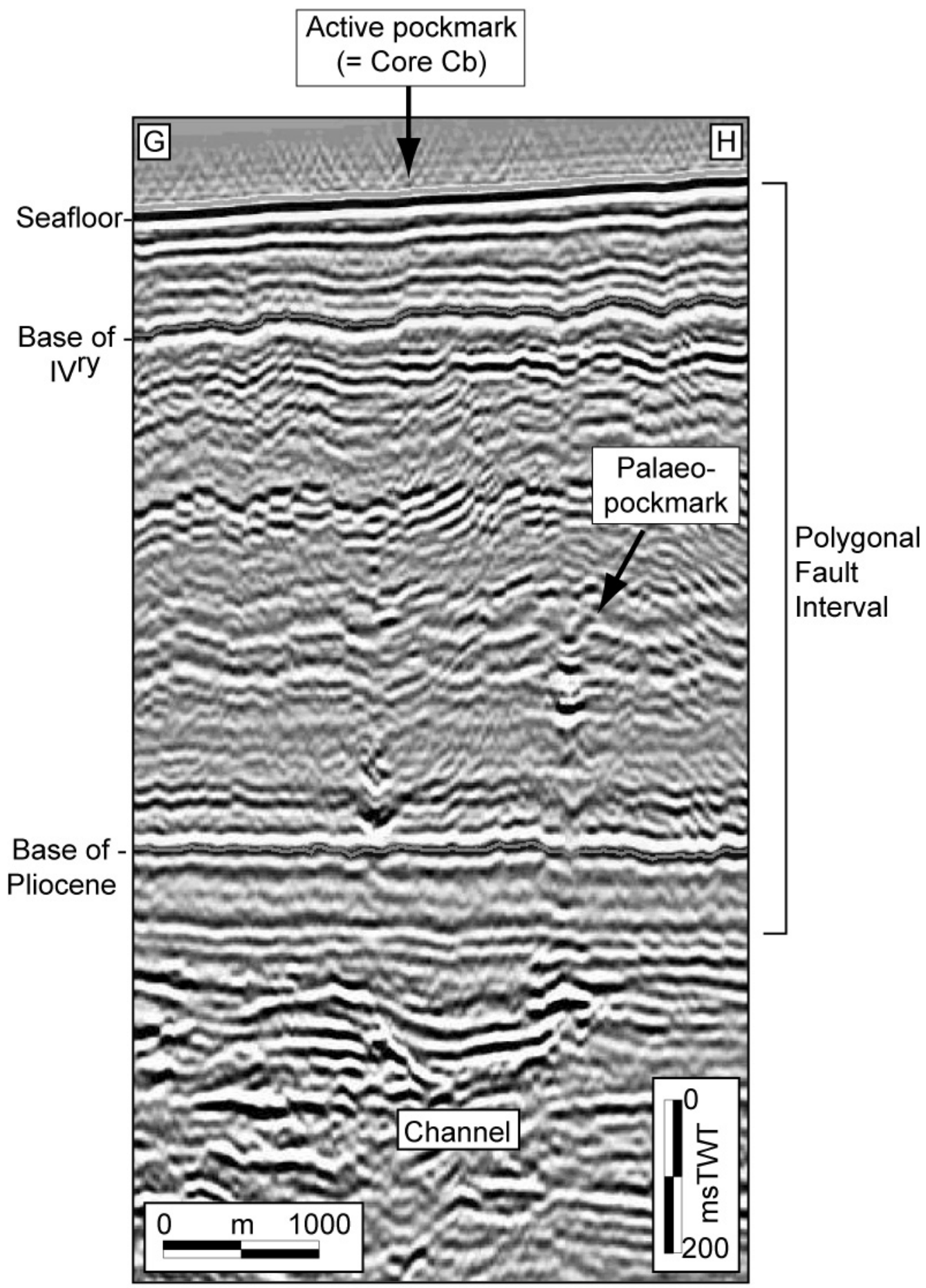

Figure 7: Seismic profile GH across the upper Miocene turbiditic channel. This profile shows two buried seismic chimneys, which seem to take root on both sides of the channel. These chimneys developed at shallower burial depth during early compaction ( Gay, Lopez, Cochonat et al., 2003). 
Geochemical analyzes realized on core $\mathrm{Cb}$ have revealed strong evidences of deep thermogenic fluids.

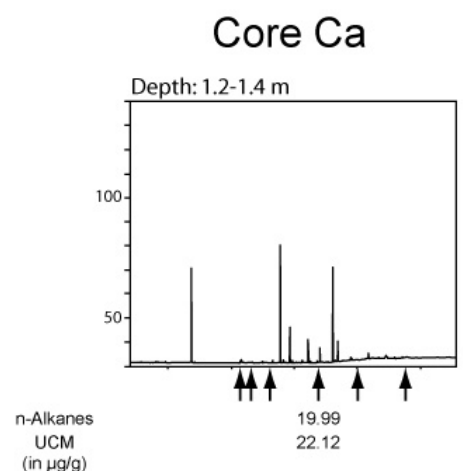

Core $\mathrm{Cb}$
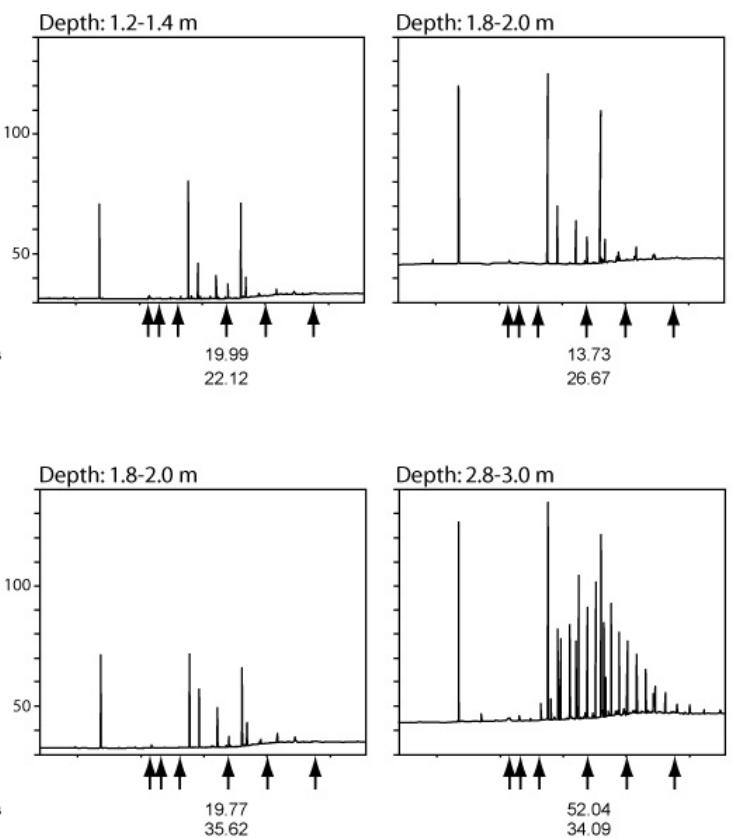

n-Alkanes
UCM
(in $\mu g / g)$
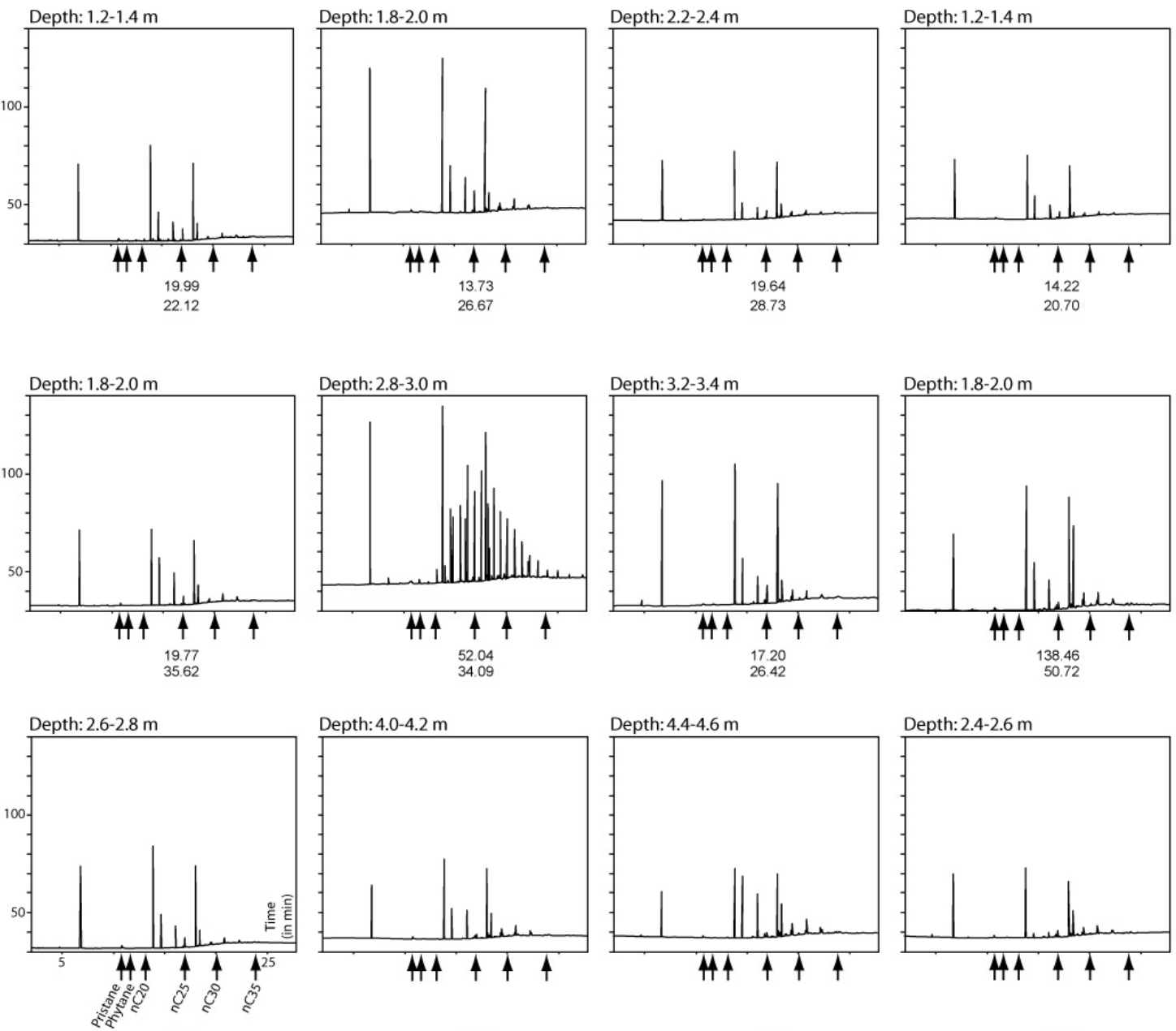

Depth:2.4-2.6 m

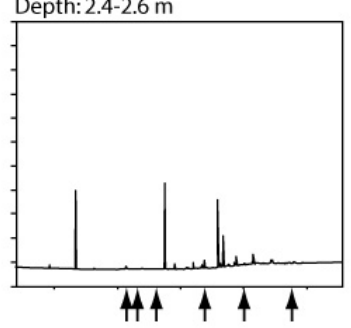

n-Alkanes
UCM
(in $\mu \mathrm{g} / \mathrm{g}$ )

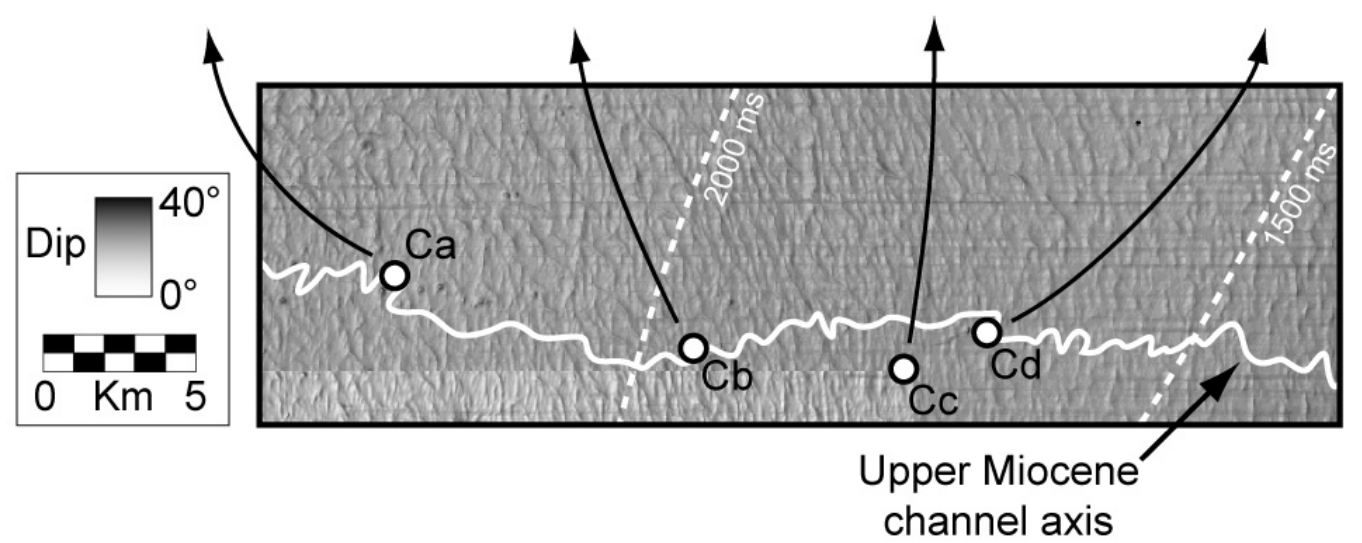

Figure 8: Diagram representing the chromatograms of the GC-MS realized on the four cores. These geochemical analyses show relatively elevated baselines (UCM $>20 \mu \mathrm{g} / \mathrm{g}$ ) and a broad molecular 
Marine and Petroleum Geology - In Press 2006

weight range of $n$-Alkanes. However, the evidence for an oil charge in shallow sediments $(0-5 \mathrm{~m})$ remains fairly tenuous if based only on a random geochemical sampling. 

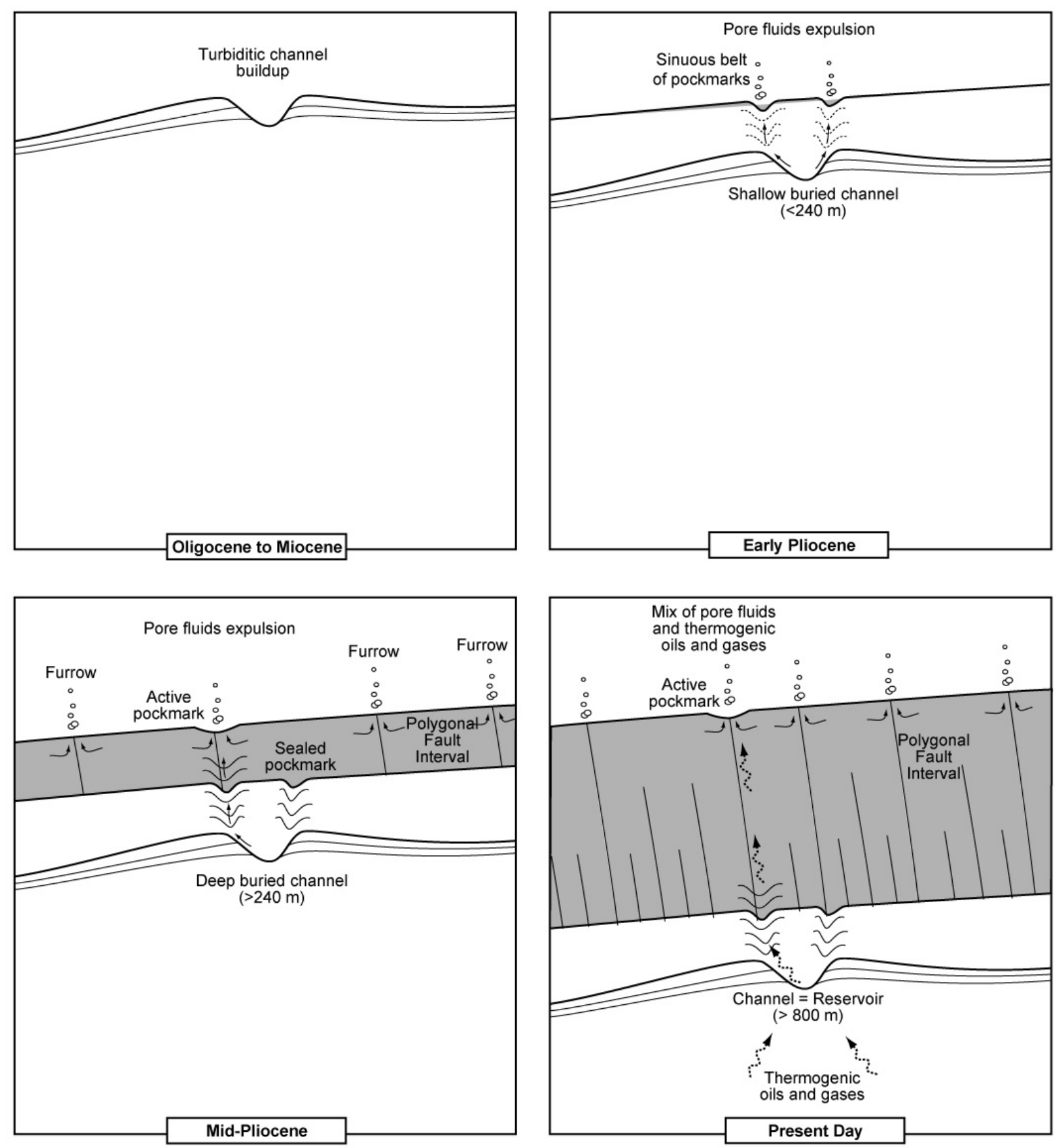

Figure 9: Dynamical model illustrating the four stages evolution of fluid migration during burial in the Lower Congo Basin. During early stages of compaction, pore fluids and biogenic fluids are expelled from 1) shallow buried channels (through chimneys) and 2) fine-grained sediments of the slope (through a polygonal fault interval). At deeper burial thermogenic fluids are preferentially entrapped within the turbiditic channel, which plays the role of a reservoir. Because of the presence of a polygonal faults, these fluids can migrate upward to cross the hydrate zone and reach the seafloor. 
Marine and Petroleum Geology - In Press 2006

\begin{tabular}{|c|c|c|c|c|c|c|c|c|c|}
\hline & Depth (m) & Imax TSF & $\begin{array}{c}\delta^{13} \mathrm{C} \\
(\mathrm{C} 1) \%\end{array}$ & $\begin{array}{c}\text { C1 } \\
\text { (ppm) }\end{array}$ & $\begin{array}{c}\text { C2 } \\
\text { (ppm) }\end{array}$ & $\begin{array}{c}\text { C3 } \\
\text { (ppm) }\end{array}$ & $\begin{array}{c}\text { iC4 } \\
\text { (ppm) }\end{array}$ & $\begin{array}{c}\mathrm{nC4} \\
\text { (ppm) }\end{array}$ & $\begin{array}{c}\text { Total C5-C7 } \\
\text { (ppm) }\end{array}$ \\
\hline \multirow[b]{3}{*}{$\mathrm{Ca}$} & $1.2-1.4$ & 902 & I & 77330 & 316 & 146 & 39 & 745 & 166900 \\
\hline & $1.8-2.0$ & 5110 & -70.32 & 73264 & 282 & 83 & 21 & 424 & 21439 \\
\hline & $2.6-2.8$ & 563 & I & 62128 & 187 & 80 & 28 & 682 & 197434 \\
\hline \multirow[b]{3}{*}{ Cb } & $1.2-1.4$ & 638 & I & 512 & 6 & 10 & 3 & 27 & 17262 \\
\hline & $1.8-2.0$ & 4095 & -86.81 & 1 & 23 & 64 & 15 & 238 & 24767 \\
\hline & $2.4-2.6$ & 2001 & I & 65443 & 286 & 26 & 2 & 20 & 12157 \\
\hline \multirow[b]{3}{*}{ Cc } & $2.2-2.4$ & 1344 & I & 36 & 8 & 39 & 24 & 120 & 232826 \\
\hline & $3.2-3.4$ & 698 & I & 29 & 8 & 46 & 21 & 87 & 86342 \\
\hline & 4.4-4.6 & 21155 & 1 & 34 & 7 & 9 & 1 & 20 & 14057 \\
\hline \multirow{3}{*}{ Cd } & $1.8-2.0$ & 2118 & I & 23 & 7 & 3 & 1 & 4 & 15314 \\
\hline & $2.8-3.0$ & 1306 & I & 125 & 9 & 4 & 2 & 4 & 31151 \\
\hline & $4.0-4.2$ & 6332 & 1 & 54 & 9 & 3 & 1 & 1 & 13098 \\
\hline
\end{tabular}


Table 1: Synthesis of geochemical analyzes conducted on the cores $(\mathrm{Ca}, \mathrm{Cb}, \mathrm{Cc}$ and $\mathrm{Cd})$ taken within four different pockmarks along the upper Miocene channel. Three samples (depth in metres below seafloor) have been analyzed for each core, showing strong concentrations of $\mathrm{C} 1$ (methane) within sediments of the cores $\mathrm{Ca}$ and $\mathrm{Cb}$. Extract yields and fluorescence intensities are relatively high (4000< Imax TSF <21000) compared to other cores from the Congo-Angola Basins $(<1000$, courtesy of TOTAL), which could be interpreted as indicating the presence of thermogenic hydrocarbons in the core. The isotopic analyzes show a value of $\delta^{13} \mathrm{C}=-70 \%$ for $\mathrm{Ca}$ and $-86 \%$ for $\mathrm{Cb}$ (relative to PDB). 